\title{
Functional properties and sensory testing of whey protein concentrate sweetened with rebaudioside $A$
}

\author{
Propriedades funcionais e teste sensorial de \\ concentrado proteico do soro do \\ leite adoçado com rebaudiosídeo A
}

Paula Gimenez MILANI ${ }^{1}$

Antonio Sérgio DACOME

Cândyce Camile Fortuna NALESSO ${ }^{1}$

Cássia Almeida FIORENTI ${ }^{3}$

Cecília Edna Mareze da COSTA ${ }^{3}$

Silvio Claudio da COSTA2

\section{A B S T R A C T}

\section{Objective}

To develop a natural dietary product with functional benefits for diabetic patients. Whey protein concentrate was obtained through the separation membrane processes and sweetened with rebaudioside A. This product was submitted to sensory testing in humans and used to evaluate possible functional properties in male Wistar rats models with diabetes Mellitus induced by streptozotocin.

\section{Methods}

Two concentrates were produced. Only the second showed protein content of 74.3 and $17.3 \%$ of lactose was used as supplementation in induced diabetic rats. This concentrate was obtained from the concentration by reverse osmosis system (180 k Daltons), followed by nanofiltration in a $500 \mathrm{k}$ Daltons membrane and spray drying at $5.0 \%$ solution of the first concentrate developed. The concentrate was sweetened with rebaudioside A (rebaudioside A $26 \mathrm{mg} / 100 \mathrm{~g}$ concentrate). All procedures were performed at the Center for Studies in Natural Products, at the Universidade Estadual de Maringá. Three experimental groups were established $(n=6)$ :

\footnotetext{
1 Universidade Estadual de Maringá, Centro de Ciências Agrárias, Programa de Pós-Graduação em Ciência de Alimentos. Av. Colombo, 5.790, Jd. Universitário, 87020-900, Maringá, PR, Brasil. Correspondência para/Correspondence to: SC COSTA. E-mail: <sccosta139@gmail.com>.

2 Universidade Estadual de Maringá, Centro de Ciências Biológicas, Departamento de Bioquímica. Maringá, PR, Brasil.

3 Universidade Estadual de Maringá, Centro de Ciências Biológicas, Departamento de Ciências Fisiológicas. Maringá, PR, Brasil.

Article based on the master's thesis of PG MILANI, entitled "Obtenção de concentrado proteico do soro do leite adoçado com rebaudiosídeo A e avaliação de suas propriedades funcionais”. Universidade Estadual de Maringá; 2013.
} 
two groups of diabetic animals, one control group and one supplemented group; and a control group of normal mice (non-diabetic). The supplemented group received concentrates sweetened with rebaudioside $A$ in a dose of $100 \mathrm{mg} / \mathrm{kg}$ bw/day by an esophageal tube for 35 days. Fasting, the fed state and body weight were assessed weekly for all groups. At the end of the supplementation period, the following were analyzed: plasma parameters of glucose, total cholesterol, triglycerides and fructosamine; the serum levels of aspartate aminotransferase and alanine aminotransferase, water and food intake. Organs and tissues were removed and weighed to assess mass and anatomical changes.

\section{Results}

The product presented $74 \%$ of proteins and $17 \%$ of lactose and showed satisfactory sensory testing by the addition of $26 \mathrm{mg}$ of rebaudioside A/100 g concentrate. Supplementation of the product reduced hyperglycemia, plasma fructosamine levels, triglycerides and total cholesterol, and improved body weight gain of streptozotocininduced diabetic rats.

\section{Conclusion}

Whey protein concentrate with substantial content of protein (above $70 \%$ ) and low lactose was obtained through the membrane separation processes. The addition of rebaudioside A at the concentration of $26 \mathrm{mg} / 100 \mathrm{~g}$ rebaudioside A proved to be as sweet as sucralose with satisfactory sensory testing, which indicates that this is a non-caloric natural sweetener that can replace artificial sweeteners. The product (whey protein concentrate sweetened with rebaudioside A) presented important functional properties and reduced the metabolic disorders caused by the syndrome.

Keywords: Diabetes Mellitus. Rebaudioside A. Whey protein concentrate.

\section{RE S U M O}

\section{Objetivo}

Obtenção de um concentrado proteico do soro do leite por meio de processos de separação por membranas, adoçado com rebaudiosídeo $A$, análise sensorial em humanos e avaliação de propriedades funcionais em modelos de ratos induzidos por estreptozotocina.

\section{Métodos}

Foram produzidos dois concentrados, mas apenas o segundo, que apresentou teor proteico de 74,3 e 17,3\% de lactose, foi utilizado na suplementação de animais diabéticos. Esse concentrado foi obtido a partir da concentração em sistema de osmose reversa (180 Daltons), seguida de nanofiltração em membrana de 500 Daltons e secagem em spray dryer de uma solução a $5 \%$ do primeiro concentrado desenvolvido. O concentrado foi adoçado com rebaudiosídeo A (26 mg de rebaudiosídeo A/100 g de concentrado) obtido por meio da extração, separação e purificação das folhas de Stevia rebaudiana. Todos os processos foram realizados no Núcleo de Estudos em Produtos Naturais, da Universidade Estadual de Maringá. Foram estabelecidos três grupos experimentais $(n=6)$ : dois de animais diabéticos, um controle e outro suplementado; e um grupo de animais não diabéticos controle. O grupo suplementado recebeu o concentrado adoçado com rebaudiosídeo A na dose de $100 \mathrm{mg} / \mathrm{kg}$ peso corporal/dia, por sonda esofágica, por um período de 35 dias. Em todos os grupos, foram avaliadas semanalmente as glicemias de jejum e no estado alimentado, e o peso corporal. Ao final do período de suplementação, os parâmetros plasmáticos de glicose, colesterol total, triglicérides e da frutosamina; os valores séricos de aspartato aminotransferase e alanina aminotransferase e a ingestão hídrica e alimentar foram analisados. Órgãos e tecidos foram retirados e pesados a fim de se avaliarem alterações de massa e anatômicas.

\section{Resultados}

O produto formulado apresentou $74 \%$ de proteínas e $17 \%$ de lactose e apresentou perfil sensorial satisfatório por meio da adição de $26 \mathrm{mg}$ de rebaudiosídeo A/100 g de concentrado. A suplementação do produto reduziu a hiperglicemia, os níveis plasmáticos de frutosamina, triglicérides e colesterol total e ainda melhorou o ganho de peso corporal dos ratos diabéticos induzidos.

\section{Conclusão}

Os processos de separação por membranas utilizados neste estudo proporcionaram a obtenção eficiente de um concentrado proteico do soro do leite, com teor proteico importante, superior a 70\% e com baixo teor de 
lactose. A adição de rebaudiosídeo $\mathrm{A}$ ao produto na concentração de $26 \mathrm{mg} / 100 \mathrm{~g}$ de rebaudiosídeo $\mathrm{A}$ proporcionou dulçor equivalente ao da sucralose, com perfil sensorial satisfatório, o que indica que esse edulcorante natural não calórico tem potencialidade para substituir os artificiais. O produto obtido (concentrado proteico do soro do leite adoçado com rebaudiosídeo A) apresentou propriedades funcionais importantes, reduzindo alguns distúrbios metabólicos decorrentes dessa síndrome.

Palavras-chave: Diabetes Mellitus. Rebaudiosídeo A. Concentrado proteico do soro do leite.

\section{INTRODUCTION}

In addition to providing energy and nutrition to the body, the current concept that food can prevent and treat diseases has driven the development of functional dietary products.

Whey, the aqueous portion left over when milk is coagulated during the process of cheese production in the production of casein ${ }^{1,2}$, is a by-product of the dairy industry that may be used to produce whey protein concentrate (whey protein concentrate) and its rate of protein ranges from 35 to $80 \%{ }^{1}$. Proteins that constitute whey protein concentrate include $\beta$-lactoglobulin and $\alpha$-lactalbumin, proteose peptone, immunoglobulins, bovine serum albumin, lactoferrin, lactoperoxidase, and some peptides such as glycomacropeptide, which is the source of Branched-Chain Amino Acids (BCAA) 3 ,4.

Athletes and individuals who practice physical exercise are the main consumers of whey protein concentrate as studies have proven its positive effects on the body structure, increase in muscle mass and fat reduction ${ }^{4,5}$.

Studies have shown that whey protein concentrate has antioxidant potential, insulinotropic, immunomodulating, antiviral and antimicrobial effects, anticancer and anti-ulcer activity, and protects the cardiovascular system ${ }^{3,4,6-11}$, which suggests it may have functional benefits to treat several diseases.

Whey protein concentrate can be obtained through membrane separation methods ${ }^{12}$ (ultrafiltration, diafiltration, and nanofiltration) with different cut-off points that result in different types of whey protein concentrate. These processes are based on the selection of particles through membranes pores and depend on pressure gradient. The processes are efficient because less energy is used, no chemical addition is required, no environmental harm is caused and lower temperature and pressure is needed.

Membrane separation processes, although they follow the same principles, have variations and depend on a number of factors. The type and characteristics of the substance that are to be isolated or concentrated must be taken into account when choosing the stages, membranes and how to carry out the process. Thus, several studies have been conducted to increase the quality of whey protein concentrate, improve the processing techniques and minimize problems such as clogging of the membrane pores, foaming, and fouling (the accumulation of unwanted particles that may damage the membrane surface), problems of selectivity and optimal concentration ${ }^{12}$. Studies also aim to reduce costs and develop new technologies to obtain products at larger scales of production to meet the growing demand. Consumers, particularly diabetics, obese or athletes, require whey protein concentrate with higher protein content and lower levels of lactose and other carbohydrates. Protein concentrates available on the market are sweetened with synthetic sweeteners such as sucralose and acesulfame- $K$, influencing the natural taste of whey protein concentrate. The plant Stevia rebaudiana Bertoni is known for having high sweetening compounds, among which are rebaudioside $A^{13,14}$, a diterpene glycoside composed of four $\beta$-D-glucopyranose units bonded to aglycone steviol ${ }^{15}$ (450 times sweeter than sucrose $)^{16,17}$ presents higher stability and solubility ${ }^{18}$, and lower bitter aftertaste. In addition to these important organoleptic properties $^{19,20}$, these non-caloric natural sweeteners 
have antioxidant and insulinotropic properties ${ }^{19,20}$ and may add functionality to foods or beverages.

The aim of the study was to develop a natural dietary product that can add functional benefits to diabetic patients. Whey protein concentrate at high protein concentration was obtained through membrane separation processes and sweetened with rebaudioside A. Sensory testing was carried out with humans and used in diabetic rat models to assess the functional properties.

\section{METHODS}

The study was conducted at the Universidade Estadual de Maringá (UEM). The processes to obtain whey protein concentrate and pure rebaudioside $A$, quantification of lactose, fixed mineral residue assessments (ash), $\mathrm{pH}$ and soluble solids ( ${ }^{\circ}$ Brix) and sensory tests were conducted at the Center for Studies in Natural Products (Nepron) of the Department of Biochemistry, following the methodology described in the literature ${ }^{12}$. The quantification of total protein and total lipids was performed at the Laboratory of Food and Water of the Department of Chemistry. The animal experiments and analyses to evaluate the functional properties of whey protein concentrate sweetened with rebaudioside A were performed at the Department of Physiological Sciences.

The whey was provided by the dairy producer Flora Milk (Flórida, Paraná, Brazil). Rebaudioside A was obtained by extraction, isolation and purification of the Stevia Redaudiana leaves of the clonal variety M1 Alvarez grown at UEM. The materials, followed by the manufacturers, were as follows: polyethersulfone membranes (Koch), 500 k Daltons (kD) membrane (Millipore), reagents for chemical and chromatographic analyses (Sigma-Aldrich Co.LLC, São Paulo, Brazil), rodent chow (Nuvilab, Nuvital Company, São Paulo, Brazil), streptozotocin (Sigma), and specific kits for the quantification of the plasma parameters (Gold Diagnostica ${ }^{\circledR}$ Ltda, Belo Horizonte, Minas Gerais, Brazil).
The system consisted of two membrane polyethersulfone filters (10-kD cut off) (Koch), reverse osmosis system composed of two 180-kD cut-off membranes (Koch); atomizer spray dryer (Büchi Labotechnik Ag, Flawil, Switzrland, model B-191), liquid chromatography (Gilson, Inc., Middleton, Wisconsin, United States, model 307); glucometer (MediSense Optium, Abbott Laboratoris, Almeda, California, United States) and spectrophotometer (Bioplus ${ }^{\circledR}$, Barueri, São Paulo, Brazil).

The process to obtain the whey protein concentrate was similar as the one described by Baldasso et al. ${ }^{12}$, which included the stages of ultrafiltration, diafiltration, and nanofiltration and spray drying. The ultrafiltration and diafiltration processes were performed using two polyethersulfone membrane filters (10-kD cut off) in a spiral configuration in parallel totaling an area of $3,5 \mathrm{~m}^{2}$. The reverse osmosis system used to obtain the concentrate consisted of two 180-kD cut-off membranes through nanofiltration using 500-kD membrane in a spiral configuration with an area of $3.5 \mathrm{~m}^{2}$ and $0.3 \mathrm{~m}^{2}$, respectively. Both membranes were made of polyamide. Whey protein concentrate was dried in an atomized spray dryer using input temperature of $170^{\circ} \mathrm{C}$ and output of $105^{\circ} \mathrm{C}$ and flow rate of $8 \mathrm{~mL} /$ minutes.

The quantification of total proteins and total lipids of whey protein concentrate was performed in accordance with the Association of Official Agricultural Chemists (AOAC) ${ }^{21}$ method, $16^{\text {th }}$ edition. The lactose concentrations were determined by high-performance liquid chromatography using a liquid chromatograph coupled with a refractive index detector and $5-\mu$ $\mathrm{NH}_{2}$ column measuring $150 \times 4.6 \mathrm{~mm}$, mobile phase of acetonitrile and water $(80: 20 \mathrm{v} / \mathrm{v})$. The assessments of fixed mineral residue (ash), $\mathrm{pH}$ and soluble solids ('Brix) were performed in accordance with the method of the Adolfo Lutz Institute ${ }^{22}$. All analyses were made in triplicate.

Rebaudioside A was obtained through extraction, isolation and purification of Stevia rebaudiana leaves of the clonal variety M1 Alvarez 
grown at Nepron, using the method developed by laboratory researchers ${ }^{23}$.

The sensory tests of the potential of rebaudioside $A$ sweetness when added to whey protein concentrate were performed by humans, after approval of the Research Ethics Committee at UEM (CAAE 18718013.3.0000.0104). Different compositions at different concentrations of rebaudioside $A$ were tested with the purpose of find one that had the sweetness equivalence of sucralose, the most common commercially available synthetic sweetener used in whey protein concentrates.

The concentration of rebaudioside A was established based on previous tests used in the composition of other products at Nepron and in the literature ${ }^{16}$. Fifteen trained tasters of both sexes, with ages between $20-55$ years, specialized in evaluating the sweetness of sweeteners were invited to participate. The duo-trio test was used for sensory assessments ${ }^{24}$.

The tasters were taken to individual cabins in a brightly illuminated (white light) room and received three coded samples, a standard one (whey protein concentrate + sucralose) and two with random numbering (whey protein concentrate + rebaudioside A and whey protein concentrate + sucralose), which were presented in different positions. The tasters were instructed to fill out a form and drink mineral water before tasting each sample. The results were submitted to the statistical tests (Analysis of Variance [Anova] and Tukey).

The procedures were approved by the Ethics Committee on animal-use experimentation of the UEM (report $n^{\circ} 120 / 2013$ ). Male Wistar rats, 35 days old and weighing $135 \mathrm{~g}$, from the Central Animal Facility at UEM were used in the study. The animals were kept at the vivarium sector under the following conditions: temperature at $24^{\circ} \mathrm{C}$, photoperiod of 12 light/dark hours, water and food ad libitum (Nuvilab ${ }^{\circledR}$, Colombo, Paraná) and kept in collective cages (46×24×20 cm), five animals per cage, or in individual metabolic cages.
The animals, 50 days old and weighing $242,5 \mathrm{~g}$, in a 12-hour fasting state were anesthetized with thiopental sodium (40 mg/kg body weight, ip) and diabetes was induced by a single intravenous administration of streptozotocin (40 mg/kg bw) dissolved in citrate buffer (0.05M; $\mathrm{pH} 4.5)^{25,26}$.

The animals that showed blood glucose levels equal or higher than $140 \mathrm{mg} / \mathrm{dL}$ in the fasting state and equal or higher than $250 \mathrm{mg} / \mathrm{dL}$ in the fed state were selected ${ }^{27}$. The levels of fasting blood glucose, blood glucose in the fed state and body weight, recorded for 3 days, were used to separate the two groups of diabetic animals so that each presented similar degrees of disease severity before starting treatment. The animals were divided into three experimental groups ( $n=6$ for each group): two groups of diabetic animals with one control and one supplemented, and one normal control group.

The one supplemented group was administered, through an esophageal tube, whey protein concentrate $(100 \mathrm{mg} / \mathrm{kg} /$ day) sweetened with rebaudioside $A$ (26 $\mathrm{mg}$ of rebaudioside A/100 mg of whey protein concentrate diluted in water) for 35 days. The dose and supplementation period was established in accordance with the literature ${ }^{9-11}$. The animals in the one control and one normal control group groups underwent the same procedure, but they only received water. Body weight, fasting glucose and blood glucose in the fed state were recorded weekly.

After 35 days of supplementation, the glycemic curve was determined and the glucose tolerance test was performed ${ }^{28}$. To determine the 12-h glycemic curve, blood samples were collected at 6 p.m. and the animals were in a 10-hour fasting state. The animals were then fed (ad libitum) and new blood samples were collected at 8 p.m., 10 p.m. and 6 a.m. The animals were kept in 12-hours overnight fasting state for the glucose tolerance test and received an oral glucose overload (1.5 g/kg body weight) after determing blood glucose at time zero. New blood samples were collected after 15, 30, 60, 90 and 
120 minutes. All blood samples were taken by caudal puncture and the glycemic levels were determined using a glucometer.

Thirty-five days after the completion of treatment, the animals were placed in individual metabolic cages to record food and water intake for 24 hours.

The animals (12-hours overnight fasting) were anesthetized with thiopental sodium (40 mg/kg body weight, ip), submitted to median laparotomy and blood samples were collected through the inferior vena cava and transferred to tubes to obtain the serum and plasma samples for biochemical tests. Euthanasia was performed by anesthetic overdose, followed by immediate removal and weighing of retroperitoneal and periependymal fat, gastrocnemius and soleus muscle, testicles, seminal vesicles, kidneys, liver and spleen.

The plasma levels of glucose, total cholesterol, triglycerides and fructosamine and serum levels of aspartate aminotransferase and alanine aminotransferase were quantified in a spectrophotometer using specific kits (Gold Analisa).

The results of all the physical-chemical analyses, sensory tests and physiological parameters were expressed as mean \pm standard error of the mean and submitted to Anova followed by Tukey's test $(p<0.05)$ due to normal distribution and because these tests are used in this type of study ${ }^{4,9-11,28}$. We used the Statistical Analysis System (SAS, Institute Inc., Cary, North Carolina, United States, 2006) statistical software version 9.1 and GraphPad Prism 5.0 program (Prism Software ${ }^{\circledR}$, Inc., La Jolla, California, United States).

\section{RE S U LTS}

Whey (thousand liters) was pasteurized and skimmed and the initial concentration of protein was $0.5 \%$ and $6^{\circ}$ Brix ultrafiltration was performed until obtaining a $75 \%$ reduction of the initial volume. At the end of the process we obtained the concentrate and permeate, which was discarded. During diafiltration, $400 \mathrm{~L}$ of distilled water were added to the system, followed by nanofiltration and sample drying $(20 \mathrm{~L})$ in a spray dryer.

Thus, the first $800 \mathrm{~g}$ of dried protein whey concentrate was obtained. The physical-chemical analyses of the concentrate showed a protein content of $58.0 \%$ and lactose content of $24.0 \%$. To obtain a concentrate with higher levels of protein and lower lactose concentration, the whey protein concentrate sample was nanofiltrated (500-kD polyamide membrane) and diafiltered. Fifteen diafiltration cycles were required (at $35^{\circ} \mathrm{C}$ ) and $2 \mathrm{~L}$ of distilled water was added to each cycle. At the end of the process, whey protein concentrate was collected for the drying process. The ${ }^{\circ}$ Brix and $\mathrm{pH}$ of the concentrate was 20 and 6.5 , respectively. This stage occurred until obtaining a concentrate volume that is $50.0 \%$ of the initial volume. The spray drying process was carried out with $600 \mathrm{~mL}$ of whey protein concentrate and a mass of $60 \mathrm{~g}$ was obtained. The final whey protein concentrate product presented a protein content of $74.3 \%$ and lactose content of $17.3 \%$.

The standard amount of sucralose to sweeten the protein concentrate was $13 \mathrm{mg} / 100$ $\mathrm{g}$ of whey protein concentrate. The sensory test of sweetness equivalence between sucralose and rebaudioside $A$ showed that only twice the quantity of rebaudioside $A$ (rebaudioside $A$ $26 \mathrm{mg} / 100 \mathrm{~g}$ of whey protein concentrate) was sufficient to promote sweetness similar to sucralose, which differs from the results found by Cardoso et al. ${ }^{29}$. The statistical analyses showed that at this concentration the tasters did not find any significant differences between the samples with sucralose and rebaudioside $A$. This composition was used for the supplementation of the experimental animals to assess the functional properties.

Figure 1 shows the development of body weight. The diabetic animals that received supplementation with whey protein concentrate 
sweetened with rebaudioside $A$ (one supplemented group) gained significantly less weight $(<0.05)$ than the diabetic control animals (one control group), showing levels closer to those observed in the normal animals (one normal control group group), as it can be seen by area under the curve values shown in detail in Figure 1.

Fasting blood glucose (Figure 2A) recorded daily during the supplementation period showed that the one supplemented group presented lower glucose levels than the one control group, with significant differences $(p<0.05)$ after 28 days of supplementation when compared to the one control group. The area under the curve values (detail in Figure 2A) prove the condition of hyperglycemia in the diabetic animals and, although lower levels were found in the one supplemented group, these were not different from those in the one control group. With regard to glycemia in the fed state (Figure 2B), the animals in the one supplemented group always presented lower glucose levels than the animals in the one control group. These differences were significant after the $14^{\text {th }}$ day of supplementation $(p<0.05)$, but no significant differences were found in the area under the curve values (detail in Figure 2B).

The glucose levels observed during oral glucose tolerance test are shown in Figure 3. The beneficial effect of supplementation was observed because all recorded blood glucose levels were lower in the one supplemented group when compared to the one control group, with significant differences $(p<0.05)$ at times 0,15 and 30 minutes. The area under the curve values (detail in Figure 3) did not show significant differences between the groups of diabetic animals.

The glycemic curve is shown in Figure 4. The glucose levels in the normal animals (one normal control group group) showed little variation at different times, which did not occur with the diabetic animals. As for the effects of supplementation, the animals in the one supplemented group showed significantly lower glucose levels in the fed state $(p<0.05), 2$ and 4 hours after food supply (blood samples collected at 8 p.m. and 10 p.m.). The area under the curve values (detail in Figure 4), although lower in the one supplemented group, did not differ significantly from the one control group.
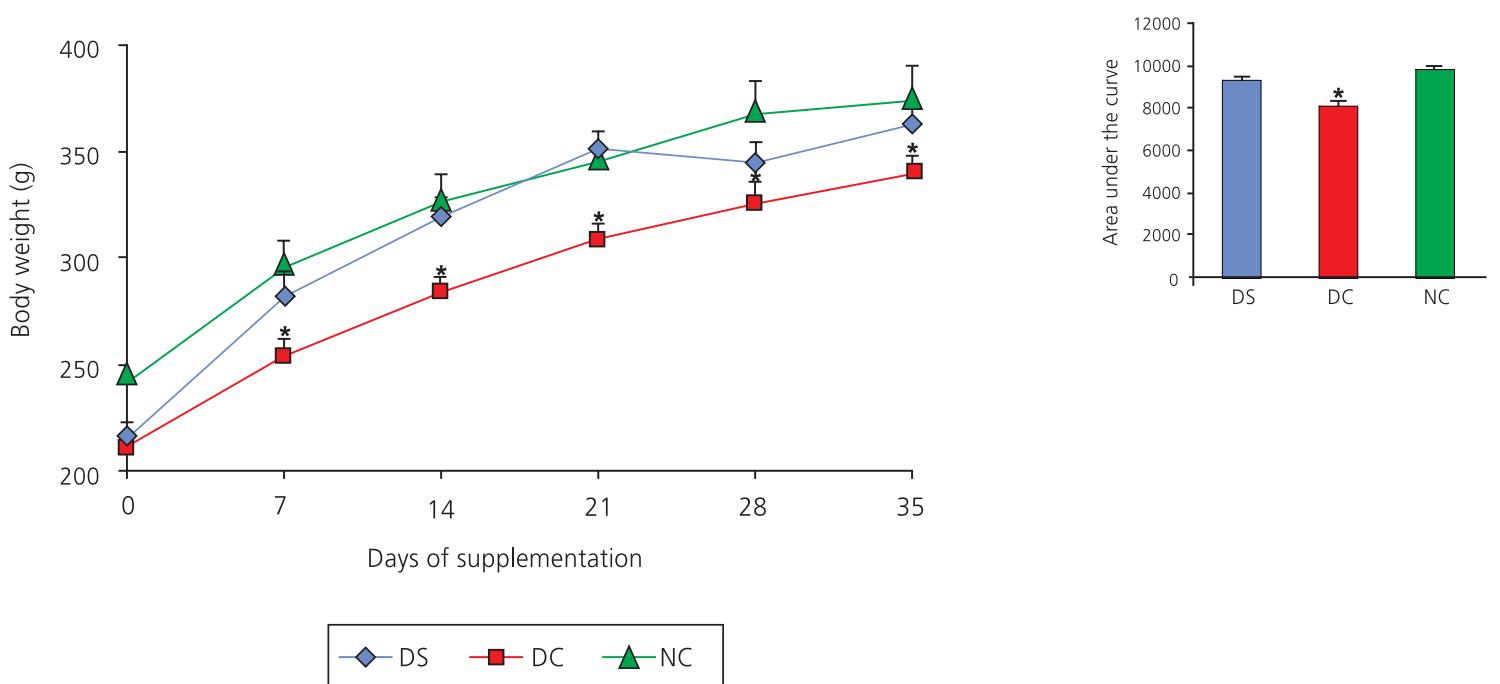

Figure 1. Effect of supplementation with whey protein concentrate sweetened with rebaudioside $A$ on the development of body weight in diabetic rats. Maringá (PR), Brazil, in 2014.

Note: ${ }^{*} p<0.05$ compared to supplemented diabetics and diabetics controls. Data express the mean \pm standard mean error. Detail of area under the curve.

DS: Supplemented Diabetics; DC: Diabetics Controls; NC: Normal Controls. 


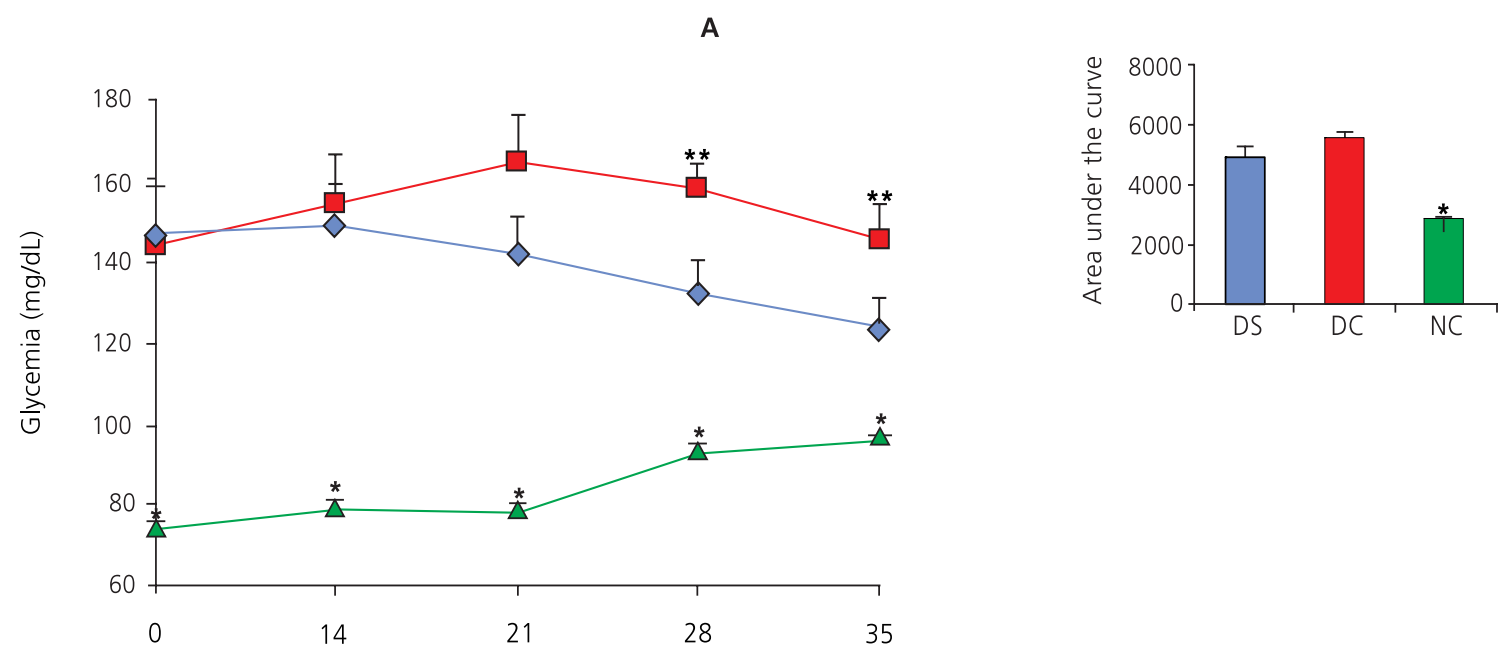

Days of supplementation

$\diamond D S \quad \square-D C \quad \triangle N C$

B
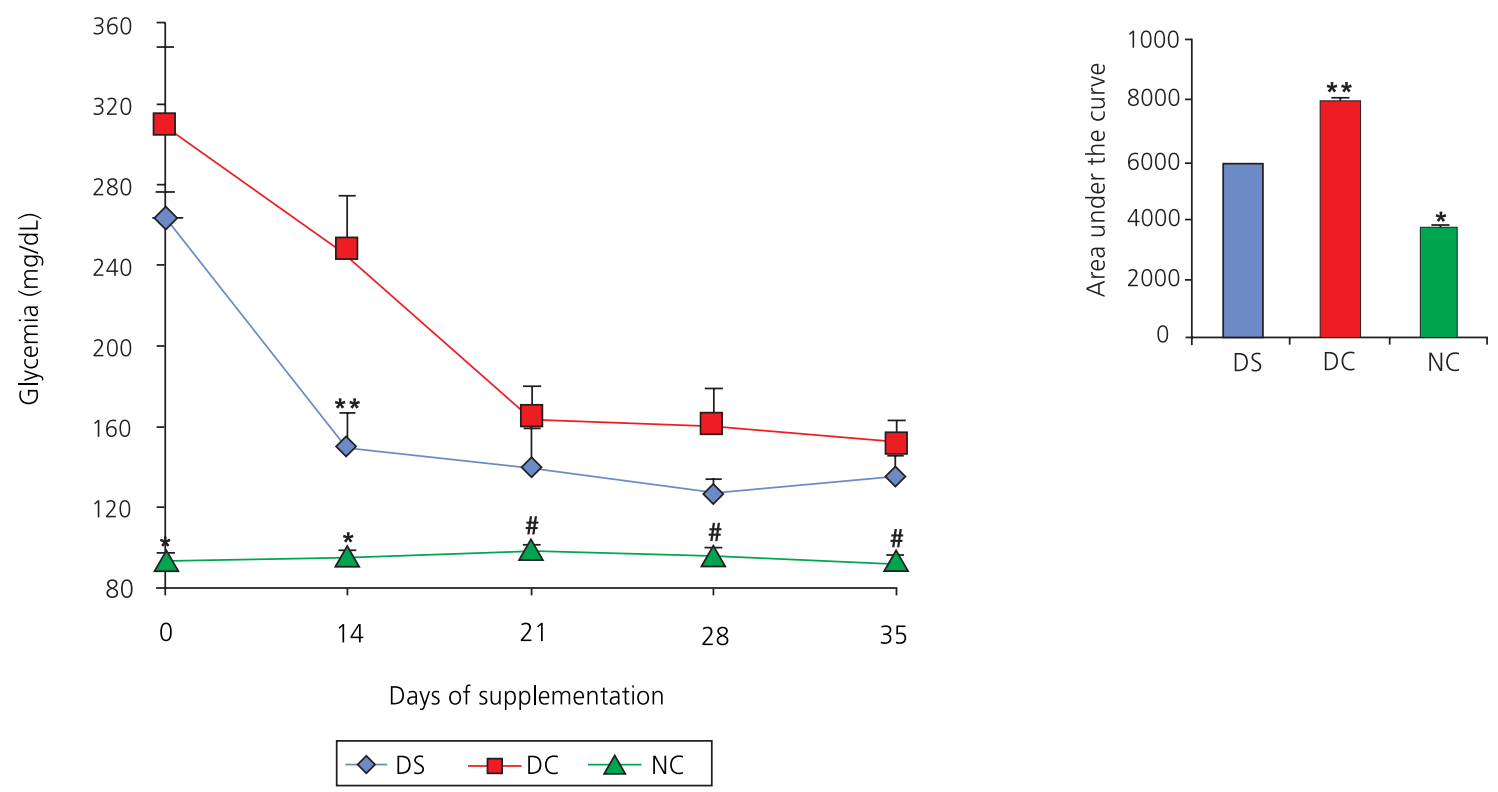

Figure 2. Effect of supplementation with whey protein concentrate sweetened with rebaudioside $A$ on fasting (2A) and fed state (2B) of diabetic rats. Maringá (PR), Brazil, in 2014

Note: ${ }^{*} p<0.05$ compared to Supplemented diabetics and diabetics controls. Data express the mean \pm standard mean error. Detail of area under the curve.

DS: Supplemented Diabetics; DC: Diabetics Controls; NC: Normal Controls.

The diabetic rats in both groups (one control and one supplemented) presented polydipsia and polyphagia, which are characteristics of the streptozotocin-induced diabetic condition. However, with regard to the effects of supplementation with whey protein concentrate 

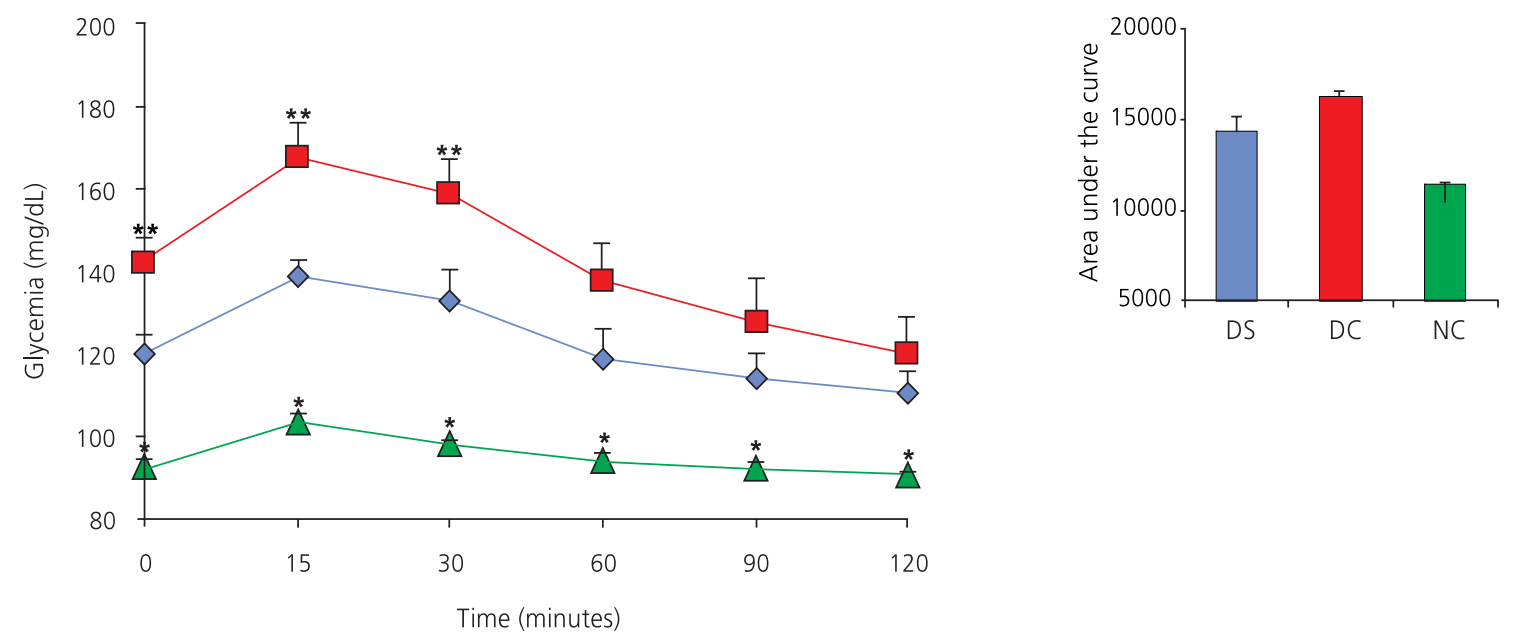

$$
\checkmark D S \neg D C \backsim N C
$$

Figure 3. Effect of supplementation with whey protein concentrate sweetened with rebaudioside $A$ on oral glucose tolerance test in diabetic rats. Maringá (PR), Brazil, in 2014.

Note: ${ }^{*} p<0.05$ compared with DS and AD; * $p<0.05$ compared to diabetics controls. Data express the mean \pm standard mean error. Detail of area under the curve.

DS: Supplemented Diabetics; DC: Diabetics Controls; NC: Normal Controls.

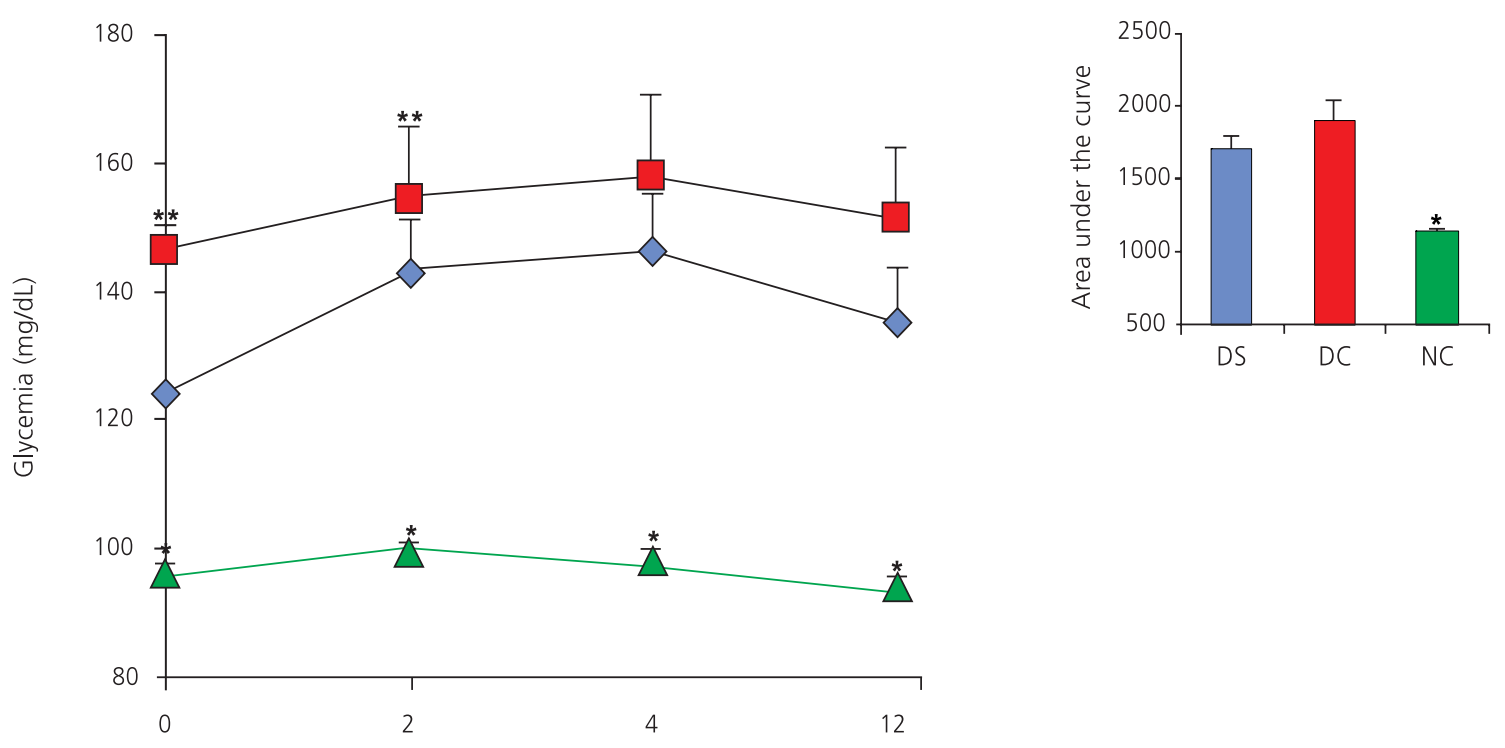

Period of 12 hours

$\diamond D S \quad \square-D C \quad \triangle N C$

Figure 4. Effect of supplementation with whey protein concentrate sweetened with rebaudioside $A$ on the glycemic curve of diabetic rats. Maringá (PR), Brazil, in 2014.

Note: ${ }^{*} p<0.05$ compared with supplemented diabetics and diabetics controls; ${ }^{* *} p<0.05$ compared to diabetics controls. Detail of area under the curve. Data express the mean \pm standard mean error.

DS: Supplemented Diabetics; DC: Diabetics Controls; NC: Normal Controls. 
Table 1. Effect of supplementation with whey protein concentrate sweetened with rebaudioside $A$ on levels of plasma glucose, fructosamine, total cholesterol and triglycerides and serum levels of aspartate aminotransferase and alanine aminotransferase of diabetic rats. Maringá (PR), Brazil, in 2014.

\begin{tabular}{|c|c|c|c|c|c|c|}
\hline \multirow{2}{*}{ Variables } & \multicolumn{2}{|c|}{ Supplemented diabetics } & \multicolumn{2}{|c|}{ Diabetics controls } & \multicolumn{2}{|c|}{ Normal controls } \\
\hline & M & SEM & M & SEM & M & SEM \\
\hline Glycemia (mg/dL) & 129.88 & 4.78 & 153.54 & $3.21^{* *}$ & 96.63 & $0.68^{*}$ \\
\hline Alanine aminotransferase (U/L) & 1.96 & 0.71 & 3.82 & 1.02 & 6.81 & $0.13^{*}$ \\
\hline Aspartate aminotransferase (U/L) & 37.21 & 2.17 & 35.50 & 2.36 & 17.13 & $0.82^{*}$ \\
\hline Total cholesterol (mg/dL) & 84.00 & 2.72 & 92.87 & $2.93^{* *}$ & 71.00 & $1.01^{*}$ \\
\hline Triacylglycerols (mg/dL) & 38.25 & 2.09 & 46.75 & $2.02^{* *}$ & 54.83 & $0.83^{*}$ \\
\hline Fructosamine (mmol/L) & 1.03 & 0.03 & 1.27 & $0.14^{* *}$ & 1.00 & 0.01 \\
\hline
\end{tabular}

Note: ${ }^{*} p<0.05$ compared with supplemented diabetics and diabetics controls]; ${ }^{* *} p<0.05$ compared to supplemented diabetics. Data express the Mean $(\mathrm{M}) \pm$ Standard Error Mean (SEM).

sweetened with rebaudioside $A$ on food and water intake, no significant differences were observed in the one control and one supplemented groups (non-sampled data).

The metabolic parameters assessed at the end of supplementation confirmed previous results, with significant reduction in hyperglycemia in the supplemented group, which beneficially reflected on the fructosamine levels, lower in the one supplemented group $(p<0.05)$ and closer to the levels found in the one normal control group group. Significant reduction $(p<0.05)$ was also found in total cholesterol and plasmatic triglyceride levels. Aspartate aminotransferase and alanine aminotransferase levels did not statistically different between the one control and one supplemented groups (Table 1).

The weight of periepididymal adipose tissue, gastrocnemius and soleus muscles, kidneys, liver, seminal vesicles and testicles did not differ between the one control and one supplemented groups (non-sampled data). Significant weight differences $(p<0.05)$ were found for the retroperitoneal fat and supplementation resulted in the reduction of adiposity $(1.00 \pm 0.09 \mathrm{~g})$ when compared with the diabetic control rats $(1.45 \pm 0.09 \mathrm{~g})$.

\section{DISCUSSION}

Ultrafiltration of whey favored protein concentration and removal of salts. The concentration factor at this stage was 6.6, similar to the results found by Baldasso et al. ${ }^{12}$. This process resulted in a product with $58 \%$ of protein and $24 \%$ of lactose, similar to the results found by Ramos et al. ${ }^{30}$. A new stage of concentration with a greater number of diafiltration cycles increased the rate of protein and reduced lactose content, corroborating the results of Pagno et al. ${ }^{1}$ and Yee et al. ${ }^{31}$, who state that the number of diafiltration cycles may proportionally increase the concentration of protein. The whey protein concentrate was spray dried at $105^{\circ} \mathrm{C}$, which is in agreement with Fang et al. ${ }^{32}$ who investigated the effect of the spray drying conditions on whey protein and concluded that solubility of proteins is higher at temperatures between $77^{\circ} \mathrm{C}$ and $107^{\circ} \mathrm{C}$ and denaturation decreases.

Different compositions of whey protein concentrate sweetened with different concentrations of rebaudioside A were prepared. Sensory tests assessed the compositions and compared whey protein concentrate sweetened with sucralose. Tests showed that a two-fold increase in the concentration of rebaudioside $A$ promoted excellent sweetness to the whey protein concentrate without significant differences between the two sweeteners. This concentration is lower than the one found in the literature that suggests 5-6 times more stevia and stevioside extracts to obtain the sweetness equivalence of sucralose $^{29}$. This is the first study that evaluates 
the addition of rebaudioside $A$ as a sweetener for whey protein concentrate, which proved to be an excellent replacement for artificial sweeteners, with a higher sweetness perception than other stevia sweeteners.

Whey protein concentrate sweetened with rebaudioside $A$ has been tested in diabetic animal models to assess the functional properties of the supplement for people with diabetes Mellitus. Prolonged hyperglycemia of patients provokes multiple disorders, causing failure of multiple organs $^{33}$. The streptozotocin-induced model of diabetes in rats causes similar metabolic changes to type 1 diabetes Mellitus ${ }^{33,34}$. The diabetic animals in the present study presented hyperglycemia, reduced body weight gain, polydipsia and increase in plasma levels of fructosamine, confirming the effectiveness of the drug in establishing the diabetes model. The daily dietary supplementation with whey protein concentrate sweetened with rebaudioside A (100 mg/kg body weight) for 35 days was efficient in mitigating the metabolic disorders resulting from this condition.

The lack or reduction of insulin action, a characteristic of diabetic individuals, causes serious alterations in the metabolism of carbohydrates, proteins and lipids, leading to loss or reduction of body weight ${ }^{35}$. The supplemented group of diabetic animals showed significantly greater body weight gain than the diabetic control animals, with levels closer to those found in the normal animals. Studies have shown that weight increase in individuals who consume whey proteins is associated with increased muscle mass which, in turn, depends on the profile of amino acids and proteins in these supplements ${ }^{35}$. Increase in weight gain cannot be explained by the data on the weight of organs and tissues that were assessed in this study, nor by the lower lipase activity or increase in lipogenesis and deposits of retroperitoneal adipose tissues, as these deposits were significantly lower in the treated diabetic animals. Studies have shown that supplementation with amino acids, particularly BCAA, affect metabolic processes that result in the reduction of body fat ${ }^{35}$. In type 1 diabetes, body fat reduction may, however, not be beneficial and the effect should be further studied.

The results in blood glucose reduction obtained in this study are in agreement with studies available in the literature ${ }^{3,7,36}$. Research involving diabetic humans and animals has shown that proteins present in protein concentrate decrease plasma glucose levels and present significant insulin tropic effects ${ }^{4,37,38}$. Rats in the one supplemented group showed a reduction in fasting glucose and in the fed state. They also showed improved metabolic control in the glycemic curve analysis and glucose tolerance test, which can be confirmed by the plasma levels of fructosamine. The reduction in the fructosamine levels proves that the metabolic control in the supplemented diabetic animals is better than in the diabetic controls.

The supplemented animals showed lower total cholesterol levels than the diabetic animals in the control group and similar results were found by Zhang et al. ${ }^{39}$. This reduction may help prevent cardiovascular diseases. Reduced triglyceride levels were also found in the supplemented animals. Mortensen et al. ${ }^{40}$ has also found lower triglyceride levels after consumption of whey protein.

\section{CONCLUSION}

The membrane separation processes and other methods described in the study were efficient to obtain whey protein concentrate with $70 \%$ of protein content. Whey protein concentrate sweetened with rebaudioside $A$ $26 \mathrm{mg} / 100 \mathrm{~g}$ provided sweetness equivalence of sucralose and satisfactory sensory perception, showing that this non-caloric natural sweetener can replace artificial ones. The product (whey protein concentrate sweetened with rebaudioside A) presented important functional properties in the metabolic control of diabetic rats. 


\section{ACKNOWLEDGEMENTS}

The authors thank Coordenação de Aperfeiçoamento de Pessoal de Nível Superior for the financial support and the dairy Flora Milk (Flórida, Paraná) for supplying the whey.

\section{REFERENCES}

1. Pagno $\mathrm{CH}$, Baldasso $\mathrm{C}$, Tessaro IC, Flores $\mathrm{SH}$, Jong EV. Obtenção de concentrados protéicos de soro de leite e caracterização de suas propriedades funcionais tecnológicas. Alim Nutr. 2009; 20(2):231-9.

2. Haraguchi FK, Pedrosa ML, Paula H, Santos RC, Silva ME. Influência das proteínas do soro sobre enzimas hepáticas, perfil lipídico e formação óssea de ratos hipercolesterolêmicos. Rev Nutr. 2009; 22(4):517-25. http://dx.doi.org/10.1590/S1415-52732009000 400007

3. Sgarbieri VC. Propriedades fisiológicas: funcionais das proteínas do soro do leite. Rev Nutr. 2004; 17(4):397-409. http://dx.doi.org/10.1590/S1415-52 732004000400001

4. Jakubowicz D, Froy O. Biochemical and metabolic mechanisms by which dietary whey protein may combat obesity and Type 2 diabetes. J Nutr Biochem. 2013; 24(1):1-5.

5. Mortensen LS, Jensen JH, Hartvigsen ML, Jensen VK, Astrup A, Vrese M, et al. Effects of different fractions of whey protein on postprandial lipid and hormone responses in type 2 diabetes. Eur J Clin Nutr. 2012; 66:709-805.

6. Scherer R, Godoy HT. Antioxidant Activity Index (AAI) by 2,2-diphenyl-1-picrylhydrazyl method. Food Chem. 2009; 112(3):654-8.

7. Pacheco MTB, Dias NFG, Baldini VLS, Tanikawa C, Sgarbieri VC. Propriedades funcionais de hidrolisados obtidos a partir de concentrados proteicos de soro de leite. Ciênc Tecnol Aliment. 2005; 25(2):333-8.

8. Frid AH, Nilsson M, Holst JJ, Bjorck IM. Effect of whey on blood glucose and insulin responses to composite breakfast and lunch meals in type 2 diabetic subjects. Am J Clin Nutr. 2005; 82(1):69-75.

9. Badr G, Mohany M, Metwalli A. Effects of undenatured whey protein supplementation on CXCL12- and CCL21-mediated B and T cell chemotaxis in diabetic mice. Lipids Health Dis. 2011; 10:203-11.

10. Badr G, Badr MB, Mahmound MH, Mohamed M, Rabah DM, Garraud O. Treatment of diabetic mice with undenatured whey protein accelerates the wound healing process by enhancing the expression of MIP- $1 \alpha$, MIP-2, KC, CX3CL1 and TGF- $\beta$ in wounded tissue. BMC Immunol. 2012; 13:32-40.

11. Ebaid H, Amir SA, Sayed A, Metwalli A. Whey protein enhances normal inflammatory responses during cutaneous wound healing in diabetic rats. Lipids Health Dis. 2011; 10:235-45.

12. Baldasso C, Barros TC, Tessaro IC. Concentration and purification of whey proteins by ultrafiltration. Desalination. 2011; 278:381-6.

13. Dacome AS, Silva CC, Costa CEM, Fontana JD, Adelmann J, Costa SC. Sweet diterpenic glycosides balance of a new cultivar of Stevia rebaudiana (Bert.) Bertoni: Isolation and quantitative distribution by chromatographic, spectroscopic, and eletrophoretic methods. Process Biochem. 2005; 40(11):3587-94.

14. Carakostas MC, Curry LL, Boileau AC, Brusick DJ. Overview: The history, technical function and safety of rebaudioside $A$, a naturally occurring steviol glycoside, for use in food and beverages. Food Chem Toxicol. 2008; 46(7):1-10.

15. SteinmetzWE, Lin A. NMR studies of the conformation of the natural sweetener rebaudioside A. Carbohyd Res. 2009; 344(18):2533-8.

16. Carvalho ACG, Oliveira RCG, Navacchi MFP, Costa CEM, Mantovani D, Dacome AS, et al. Evolution of the potencial use of rebaudioside-A as sweetener for diet jam. Food Sci Technol. 2013; 33(3):555-60.

17. Goto A, Clemente E. Influência do rebaudiosídeo A na solubilidade e no sabor do esteviosídeo. Ciênc Tecnol Aliment. 1998; 18(1):3-6.

18. Williams LD, Burdock GA. Genotoxicity studies on a hight-purity rebaudioside A preparation. Food Chem Toxicol. 2009; 47(8):1831-6.

19. Tadhani MB, Patel VH, Subhash R. In vitro antioxidant activities of Stevia rebaudiana leaves and callus. J Food Comp Anal. 2007; 20(3):323-9.

20. Abudula R, Matchkov VV, Jeppensen PB, Nilsson $H$, Aalkjær C, Hermansen K. Rebaudioside A directly stimulates insulin secretion from pancreatic beta cells: A glucose-dependent action via inhibition of ATP-sensitive K+-channels. Diabetes Obes Metab. 2008; 10(11):1074-85.

21. Association of Official Agriculture Chemists. Official methods of analysis of AOAC International. $16^{\text {th }}$ ed. Arlington (VA): Association of Analytical Communities; 1995.

22. Instituto Adolfo Lutz. Normas Analíticas do Instituto Adolfo Lutz: métodos químicos e físicos para análises de alimentos. $4^{\text {a }}$ ed. São Paulo: IMESP; 2005. vol.1.

23. Costa SC, Costa CEM, Dacome AS, Diniz SPSS, Fernandes LM, Lima COM, et al., inventors. Estudos 
biotecnológicos de Stevia rebaudiana (Bert) Bertoni, 2005, Brasil. Patente 1133/2005. 2005 maio 27.

24. Dutcosky SD. Análise sensorial de alimentos. $4^{\mathrm{a}}$ ed. Curitiba: Universitária Champagnat; 2013.

25. Szkudelski T. The mechanism of alloxan and streptozotocin action in B cells of the rat pancreas. Physiol Res. 2001; 50(6):537-46.

26. Junod A, Lambert AE, Stauffacher W, Renold AE. Diabetogenic action of streptozotocin: Relationship of dose to metabolic response. J Clin Invest. 1969; 48(11):2129-39.

27. King AJF. The use of animal models in diabetes research. Br J Pharmacol. 2012; 166(3):877-94.

28. Matsuda M, DeFronzo RA. Insulin sensitivity indices obtained from oral glucose tolerance testing: Comparison with the euglycemic insulin clamp. Diabetes Care. 1999; 22(9):1462-70.

29. Cardoso JMP, Battochio JR, Cardello HMAB. Equivalência de dulçor e poder edulcorante de edulcorantes em função da temperatura de consumo em bebidas preparadas com chá-mate em pó solúvel. Ciênc Tecnol Aliment. 2004; 24(3):448-52.

30. Ramos OL, Pereira JO, Silva SI, Amorim MM, Fernandes JC, Lopes-da-Silva JA, et al. Effect of composition of commercial whey protein preparations upon gelation at various $\mathrm{pH}$ values. Food Res Int. 2012; 48(2):681-9.

31. Yee KWK, Wiley DE, Bao J. Whey protein concentrate production by continuous ultrafiltration: Operability under constant operating conditions. J Membrane Sci. 2007; 290(1-2):125-37.

32. Fang $Y$, Rogers S, Selomuya C, Chen XD. Functionality of milk protein concentrate: Effect of spray drying temperature. Biochem Engineering J. 2012; 62:101-5.
33. Elsner M, Guldbakke B, Tiedge M, Munday R, Lenzen S. Relative importance of transport and alkylation for pancreatic beta-cell toxicity of streptozotocin. Diabetologia. 2000; 43(12):1528-33.

34. Carvalheira JBC, Zecchin HG, Saad MJA. Vias de sinalização da insulina. Arq Bras Endocrinol Metab. 2002; 46(4):419-25.

35. Haragushi FK, Abreu WC, De Paula H. Proteínas do soro do leite: composição, propriedades nutricionais, aplicações no esporte e benefícios para saúde humana. Rev Nutr. 2006; 19(4):479-88. http://dx.doi.org/10.1590/S1415-5273200600040 0007

36. Takasaki K, Nakajima T, Ueno K, Nomoto Y, Higo K. Effects of combination treatment with dipeptidyl peptidase IV inhibitor and sulfonylurea on glucose levels in rats. J Pharmacol Sci. 2004; 95(2):291-3.

37. Jain SK. L-cysteine supplementation as an adjuvant therapy for type-2 diabetes. Can J Physiol Pharmacol. 2012; 90(8):1061-4.

38. Oliveira FCE, Volp ACP, Alfenas RC. Impact of different protein sources in the glycemic and insulinemic responses. Nutr Hosp. 2011; 26(4):669-76.

39. Zhang X, Beynen AC. Lowering effect of dietary milk-whey protein v. casein on plasma and liver cholesterol concentrations in rats. Br J Nutr. 1993; 70(1):139-46.

40. Mortensen LS, Hartvigsen ML, Brader LJ, Astrup A, Schrezenmeir J, Holst JJ, et al. Differential effects of protein quality on postprandial lipemia in response to a fat-rich meal in type 2 diabetes: Comparison of whey, casein, gluten, and cod protein. Am J Clin Nutr. 2009; 90(1):41-8.

Received: December 11, 2014 Final version: September 9, 2015 Approved: September 29, 2015 
